\title{
The Role Of Digital Banking In Taking The Opportunities And Challenges Of Sharia Banks In The Digital Era
}

\author{
Sutikno Sutikno ${ }^{1}$,Nursaman Nursaman ${ }^{2}$, Muliyati Muliyati ${ }^{3}$ \\ 1,2Finance and Banking, Serang Raya University, Banten, Indonesia \\ ${ }^{3}$ Institut Bisnis dan Informasi Kosgoro 1957, DKI Jakarta, Indonesia
}

\begin{tabular}{|c|c|}
\hline A R T I C L E I N F O & ABSTRACT \\
\hline Article history: & \multirow{8}{*}{$\begin{array}{l}\text { Rapid technological developments gave birth to digital banking or better known as } \\
\text { digital banking. How to prepare Islamic banks in taking opportunities and challenges } \\
\text { in the digital era. sharia banking in Tangerang city in facing the digital era. This } \\
\text { study uses a qualitative method with a phenomenological approach to find the } \\
\text { opportunities and challenges of Islamic banks in the digital banking era. Data } \\
\text { collected through observation, interviews, and documentation. The results of this } \\
\text { study found that there are opportunities and challenges that faced by Islamic banks } \\
\text { in the digital era, namely; 1) the convenience felt after the emergence of digital } \\
\text { banking begins with the convenience of transactions without having to go to a direct } \\
\text { bank. 2) digital banking is a sharia concept based on Islamic religious teachings } \\
\text { which is far from usury. 3) accelerates the activities of Islamic banks in Malay This } \\
\text { is the customer. The challenges experienced by Islamic banks in this digital banking } \\
\text { era are due to the high level of competition against conventional banks and the delay } \\
\text { in internet networks that are always lagging behind. }\end{array}$} \\
\hline $\begin{array}{l}\text { Received Dec 22, } 2021 \\
\text { Revised Dec 30, } 2021 \\
\text { Accepted Jan 30, } 2022\end{array}$ & \\
\hline Keywords: & \\
\hline Islamic Banking; & \\
\hline Digital Banking; & \\
\hline Obstacles; & \\
\hline Opportunities and & \\
\hline Challenges. & \\
\hline
\end{tabular}

Corresponding Author:
Sutikno,
Finance and Banking,
Serang Raya University,
Jl. Raya Serang - Cilegon KM 5, Taman Drangong Serang, Banten, Indonesia
Email: sutikno.se.mm@gmail.com

\section{Introduction}

Known as digital banking, or digital banking, because of the rapid development of technology that accelerates the financial activities of all clients. The Indonesian people appreciate digital banking services today because the convenience that banks provide to their customers makes them happy. It is known that around $74 \%$ of Indonesians have access to banking services and the rest have not been touched by banking (Marlina \& Humairah, 2018). Fiber optic to SMS banking and other banking products can be accessed through digitization. For this reason, banks consider how people can open, save, apply for loans, apply for loans and other banking services without having to come directly to the bank branch concerned. Banks see this as a potential and opportunity to be loyal to the bank by increasing the interest of prospective customers and making them bank customers who provide the services they need according to their needs (Susilawaty \& Nicola, 2020). The banking industry has recently introduced digital banking services. The advantages that banks can take to advance digital banking are the surge in cellular and cellular users which are currently growing very rapidly, and Islamic Banks are social technology media for cellular users (Werdi Apriyanti, 2018). This can be done in such a way that it is very important for Islamic digital banks to provide comprehensive and satisfying services to their customers.

In today's digital era, Islamic banks need to be more responsive using current technology to provide simple, fast and secure services (Rafiki, 2020). One strategy that can be used to develop banking digitalization 
is to work with technology companies, especially telecommunications. Telecommunication companies almost certainly have advanced technology that can help digitize the banking world (Nengsih, 2015). A common problem in the digital banking world is that the internet is getting slower. As a result, despite decades of doing business, only a quarter of Indonesia's population has access to banking services. In this context, consumer data and information, such as consumer data (behavior), products that consumers need today, what business models are appropriate, and how banks relate to customers (Rumondang et al., 2019). There are still many banks that have problems with this internet network because they have companies, banks and consumers. A phenomenon that often occurs in the banking industry, especially in the city of Tangerang, is the intense competition between traditional banks and Islamic banks to foster customer interest in saving in banks which are detrimental to customers with internet banking. , Mobile banking, SMS banking, ATM services. With the presence of Digital Banking in the community, customers can easily make transactions without having to go directly to a digital bank. Digital is a journey that requires investment and careful planning to make decisions about the future of the bank's business (Sutikno \& Irwani Abdullah, 2021). This puts banks at risk, but if they don't understand it, it will hurt the franchise that has been built over generations. As time goes by, Islamic banks are growing rapidly, and Islamic banks are starting to increase their efforts to attract customers by improving quality and service and offering new products that are attractive to them. The proliferation of digital banking today has a major impact on environmental change, changing the way of thinking and behaving in deciding which bank to suit the needs of society. The importance of this research needs to be studied further so that banks can take the right decisions to adopt digital banking in order to take advantage of the opportunities and challenges faced by banks.

\section{Research Method}

This research design uses a qualitative approach with a phenomenological approach which aims to identify the opportunities and challenges faced by Islamic banks in facing the digital era. (Prsetyo, 2011) Qualitative research seeks to understand the phenomena experienced by research through topics. Lives in a city in the Tangerang area where the respondent is located, uses various scientific methods in a specific context, through explanations through the leadership of an employee at one of the Islamic banks that has the authority at the branch office

\section{Results}

Fundamentally, knowledge comes from the interaction between the researcher and the research subject, and this research provides some insights. It is divided into several topics at once when creating a written work. Or in a different kind of writing, if the topic is basic, like at home, there must be a topic. Therefore, the most important thing for the reader is the topic. If the topic is beautiful, readers will be interested in reading it and will also add deep value to the writing. Topic also means the meaning of the written work so that the topic can be understood, and then researched in more detail what some subjects find very interesting. As researchers prepare Islamic banks for the current era of digital banking, Islamic banks will experience many changes in the digital banking era and will increase over time as digital banking improves. Therefore, Islamic bank employees will inevitably develop. There are many things that can be learned about the convenience that can be obtained after the existence of digital banking. The results of further research are the opportunities and challenges of Islamic banks from the perspective of the digital banking era. In short, Islamic banks will have a tremendous opportunity to promote social contacts and provide ease of transaction processing to customers after digital banking. But apart from that, Islamic banks continue to face challenges such as intense competition between traditional banks and Islamic banks and the lack of public understanding of internet banking used in the banking industry, even after entering digital banking. In this study, researchers collaborate with Islamic banks in the digital era to provide good cooperation within the framework of Sharia law: institutions, Talim demonstrations, mosques, and all things Islamic. 


\section{Conclusion}

Based on the findings of the Tangerang Islamic Commercial Bank using a qualitative approach with a phenomenological approach, it can be concluded that: (a). Bank preparation in the current digital era, namely providing fast, practical and uninterrupted digital services. Islamic banks must be ready to quickly predict system problems in order to serve their customers. Informants believe that the preparation of a sharia banking system is not limited to technology, but banking is still based on sharia principles. Religion is first; (b). Today's Islamic banks are in the era of digital banking, especially because in today's society the majority of Indonesian Muslims need a simple and fast process to enable transactions that save time and money. Opportunities Indeed, we need banks that continue to prioritize sharia principles. That way, the presence of digital banking can provide a great opportunity to increase customer interest in saving at Islamic banks. The challenges for Islamic banks are the reliability and security of Internet banking which has not improved, and the increasing competition between Islamic banks and traditional banks, which is certainly a challenge. for Islamic banks; (c). The efforts of Islamic banks in facing the digital banking era are socializing and encouraging the introduction of Islamic banking functions that are still based on sharia principles and the provisions of Allah SWT. Sumber believes that increasing socialization and collaboration with congregations, mosque charities, and laziz in the city of Tangerang is better for introducing Islamic banking to the wider community. This study also identifies differences that occur before and after the existence of digital banking. This provides a significant level of work comfort for employees and makes it easier for customers to handle transactions that were previously made directly to the bank and transactions after digital banking. You can access banking services without having to go directly to the bank. In today's digital era, banks have more and more service capabilities to meet the needs of their customers.

\section{References}

Aisyah, M. (2018). Islamic Bank Service Quality and Its Impact on Indonesian Customers' Satisfaction and Loyalty. AlIqtishad: Jurnal Ilmu Ekonomi Syariah, 10(2). https://doi.org/10.15408/aiq.v10i2.7135.

Arthantri, D. (2021). The Effect Of Marketing Mix On Students Loyalty Towards Instant Noodles With The Brands of INDOMIE, SEDAP, and ABC With Moderated Variety Seeking. Journal of Management Science (JMAS), 4(3), 83-92. https://doi.org/10.35335/jmas.v4i3.108

Kholis, N. (2020). PERBANKAN DALAM ERA BARU DIGITAL. Economicus, 12(1), 80-88. https://doi.org/10.47860/economicus.v12i1.149

Liaanjani, D., \& Sutikno, S. (2021). Restructuring As An Effort To Reduce The Impact Of Problem Financing On Griya Ib Hasanah Produc. Jurnal Keuangan Dan Perbankan (KEBAN), 1(1), 44-51. https://doi.org/10.30656/jkk.v1i1.3969

Lubis, C., Nugroho, L., Fitrijanti, T., \& Sukmadilaga, C. (2020). Peluang Pengusaha Mikro dan Kecil (UMK) Menggunakan Layanan Digital Lembaga Keuangan Mikro Syariah. JURNAL AL-QARDH, 5(1), 56-68. https://doi.org/10.23971/jaq.v5i1.1769

Ramadani, M., \& Sutikno, S. (2021). Commitment Of Small Business Actors To Shopee Online Consumers. Primanomics: Jurnal Ekonomi \& Bisnis, 19(3), 91-100. https://doi.org/10.31253/pe.v19i3.638

Marlina, A., \& Humairah, F. (2018). PERAN DIGITAL BANKING DALAM MENINGKATKAN KEPUASAN NASABAH KREDIT (STUDI KASUS PT.BANK TABUNGAN NEGARA SYARIAH). Moneter: Jurnal Keuangan Dan Perbankan, 6(2), 37. https://doi.org/10.32832/moneter.v6i2.2409

Meliana, A. A. (2017). Factors Affecting Customer Satisfaction with Services at Bank Safir Bengkulu City (in terms of product and financing).

Mohamed, H., \& Ali, H. (2018). Blockchain, Fintech, and Islamic Finance. De Gruyter. https://doi.org/10.1515/9781547400966

Nainggolan, A. A. (2017). Application of Micro Stall Financing Products at Bank Syariah Mandiri Kc. Pematangsiantar. Universitas Islam Negeri Sumatera Utara.

Nengsih, N. (2015). Peran Perbankan Syariah Dalam Mengimplementasikan Keuangan Inklusif di Indonesia. ETIKONOMI, 14(2). https://doi.org/10.15408/etk.v14i2.2272

Nugroho, L., Hidayah, N., \& Badawi, A. (2018). The Islamic Banking, Asset Quality: "Does Financing Segmentation Matters" (Indonesia Evidence). Mediterranean Journal of Social Sciences, 9(5), 221-235. https://doi.org/10.2478/mjss-2018-0154

Prsetyo, T. (2011). Micro Stall Financing Products at Bank Syariah Mandiri Depok Kelapa Dua Branch.

Rafiki, A. (2020). Opportunities and Challenges of Social Media to the Islamic Banks in Indonesia (pp. 227-251). https://doi.org/10.4018/978-1-7998-2257-8.ch011

Rumondang, A., Sudirman, A., Effendy, F., Simarmata, J., \& Agustin, T. (2019). Fintech: Inovasi Sistem Keuangan di Era Digital. Yayasan Kita Menulis. 
Salam, A. (2018). Inklusi Keuangan Perbankan Syariah Berbasis Digital-Banking: Optimalisasi dan Tantangan. AlAmwal : Jurnal Ekonomi Dan Perbankan Syari'ah, 10(1), 63. https://doi.org/10.24235/amwal.v10i1.2813

Susilawaty, L., \& Nicola, N. (2020). Pengaruh layanan perbankan digital pada kepuasan nasabah perbankan. Jurnal Manajemen Maranatha, 19(2), 179-190. https://doi.org/10.28932/jmm.v19i2.2478

Simbolon, A. (2021). Analysis of Factors Affecting the Amount of Credit Distribution at Credit Unions. Journal of Management Science (JMAS), 4(3), 98-100. https://doi.org/10.35335/jmas.v4i3.110

SULISTYA, A. (2017). THE EFFECT OF MURABAHAH FINANCING, ENTREPRENEURSHIP TRAINING AND BUSINESS EXPERIENCE ON INCREASING INCOME OF MICRO SMALL AND MEDIUM BUSINESS (MSMES) AT BANK MUAMALAT KCP BLITAR.

Sumarno, S. (2017). The Effect of Financing, Entrepreneurship Training, and Self-Efficacy on Entrepreneurial Intentions of Posdaya Berkah V Kalinyamat Wetan Tegal City. Jurnal Ilmiah Ekonomi Dan Bisnis Unilak, 14(1), 82-87.

Sutikno, S., \& Irwani Abdullah, N. (2021). The Impact of Islamic Banks in Financing MSMEs in Serang City. Jurnal Keuangan Dan Perbankan (KEBAN), 1(1), 14-25. https://doi.org/10.30656/jkk.v1i1.3965

Sutikno, S., \& Kuruppuarachchi, D. (2021). Finance Technology as a Solution to Get Capital for Small Business Today. Jurnal Keuangan Dan Perbankan (KEBAN), 1(1), 1-13. https://doi.org/10.30656/jkk.v1i1.3964

Sutikno, S., \& Suhartini, S. (2020). Prices trategies and promotions which E-Commerce does in sales. Primanomics : Jurnal Ekonomi \& Bisnis, 18(3). https://doi.org/10.31253/pe.v18i3.399 